\title{
Hepatitis A Antibody Seroprevalence in a Selected Kenyan Pediatric Population
}

\author{
Aggrey Wasunna ${ }^{*}$, Florence Murila1, Moses M. Obimbo², Mwaswere J. Rama ${ }^{3}$, Horatius Musembi ${ }^{4}$ \\ ${ }^{1}$ Department of Pediatrics and Child Health, University of Nairobi, Nairobi, Kenya \\ ${ }^{2}$ Department of Human Anatomy, Obstetrics and Gynecology, University of Nairobi, Nairobi, Kenya \\ ${ }^{3}$ Department of Nursing Sciences, Pwani University College, Kenyatta University, Kahawa, Kenya \\ ${ }^{4}$ Cicelly McDonell School of Nursing, the Nairobi Hospital, Nairobi, Kenya \\ Email: *aggrey.wasunna@uonbi.ac.ke
}

How to cite this paper: Wasunna, A., Murila, F., Obimbo, M.M., Rama, M.J. and Musembi, H. (2016) Hepatitis A Antibody Seroprevalence in a Selected Kenyan Pediatric Population. Open Journal of Pediatrics, 6, 316-323.

http://dx.doi.org/10.4236/ojped.2016.64043

Received: November 14, 2016

Accepted: December 11, 2016

Published: December 14, 2016

Copyright $\odot 2016$ by authors and Scientific Research Publishing Inc. This work is licensed under the Creative Commons Attribution International License (CC BY 4.0).

http://creativecommons.org/licenses/by/4.0/

\begin{abstract}
The incidence of infection by Hepatitis A virus shows regional variation being highest in developing countries. Determination of age specific Hepatitis A virus (HAV) seroprevalence and the associated risk factors would help better plan for national preventive strategies including vaccination. We carried out a cross-sectional study on 300 children from Nairobi city, Kenya during the years 2003-2004. The age range of the children was 2 - 14 years and were from low and high socioeconomic status (SES) families. The indicators of SES included employment status, residence, number of children per patient's household, parents' level of education and source of drinking water. SES was encoded and analysed using Statistical Program for Social Sciences (SSPS) version 16.0. Seroprevalence increased significantly with advancing age. Seropositivity of HAV antibodies was significantly higher among children of low SES, $77.6 \%$ by the age of 14 years compared to children of high SES, $38.9 \%$ by the same age. Crowded household and parental education were significantly associated with high seropositivity and seronegativity respectively. There is significant rate of seronegativity amongst the studied population especially those from richer backgrounds making them more susceptible to severe infection in future with concomitant complications. We propose that revision of national vaccination program should be considered to include Hepatitis A vaccination.
\end{abstract}

\section{Keywords}

Seroprevalence, Hepatitis A, Pediatrics

\section{Introduction}

The infection due to Hepatitis A virus (HAV) is on epidemiological transition globally 
with changing patterns in respect with economic fortunes. Certain regions of the world are known to have the highest endemicity including Asia, Africa and parts of the Caribbean, South, Central America. Economic factors leading to high endemic levels include lack of proper housing and water sanitation, overcrowding and poverty [1] [2]. The virus is transmitted via the feco-oral route and its exact impact is always underestimated due to mildly symptomatic or asymptomatic nature of the infection [3] [4]. There is considerable variation in the rates of seroprevalence by region, country and intra-country with marked fluctuations from time to time but in general the underdeveloped countries bear the greatest disease burden amongst children at an earlier age. Coincidentally, these infections are mild to asymptomatic and most of the children attain immunity by the time they reach adolescence [5]. On the contrary, developed countries are characterized by low antibody seroprevalence of HAV during childhood which continues to adulthood where roughly $50 \%$ of the adult population is seronegative and consequently at risk of severe forms of hepatitis A infection [6] [7].

With improving economic fortunes of most developing nations, the epidemiologic pattern of HAV is expected to shift and may demonstrate patterns similar to those of developed countries. This has the potential of putting the adult population at risk of severe hepatitis A infection [8]. Although Hepatitis A virus infection can easily and effectively be mitigated through vaccination [9], this has not been fully implemented and included in the national vaccination programs of many countries including Kenya. As a result, there is likelihood of witnessing more adult morbidity and mortality resulting from HAV infection. This study aimed at determining the age specific HAV antibody seroprevalence and the associated risk factors which would help better plan for national preventive strategies including vaccination.

\section{Patients and Methods}

Three hundred children from Nairobi, Kenya aged between two and fourteen years without a history of vaccination against hepatitis A, signs of hepatitis or jaundice and had lived in the present accommodation or similar one in Nairobi from birth were included in the study. This study was done between year 2003 and 2004 in Nairobi City, Kenya. Three hundred children were included in this study but only 256 were analysed. The sample size was calculated based on prevalence of previous studies and considering $80 \%$ power. The children were subdivided into three age groups: $2-4,5-9,10-14$ years.

Permission to carry out the study was obtained from Kenyatta National Hospital/ University of Nairobi Ethics and Review committee and the Aga Khan University Hospital Education committee. Informed consent obtained from the parents before the children were included in the study. A structured questionnaire developed by the principal investigator in this study and his team was used to collectd emographic data and evaluate the socioeconomic status (SES) of the subjects after pilot and proper validation of the tools. The indicators of SES included employment status, residence, number of children per patient's household, parents' level of education, source of drinking water. 
Socioeconomic status (SES) was encoded and scored as summarized in Table 1: Each attribute was assigned 1 or 2 point(s) in column 1 and 2 respectively. Total score was then calculated. A score of 6 or less was deemed as high SES while a score of $7-12$ was judged as low SES.

Alongside the questionnaire, $2 \mathrm{~mL}$ of blood was drawn from each patient by venous puncture through a sterile procedure and collected into a vacutainer tube. Whole blood was centrifuged at $3000 \mathrm{rpm}$ for 15 minutes to obtain a serum sample which was then stored in cryotubes at $-20^{\circ} \mathrm{C}$ within 24 hours of sampling. Enzyme-linked immunosorbent assay (ELISA; HAVAB-EIA; Abbot Diagnostics, Illinois, USA) was used to determine the presence of HAV antibodies.

Data obtained were entered and analyzed using SPSS version 16.0 Chicago Illinois. Student $\mathrm{t}$ test was used for comparing qualitative variables. Logistic regression analysis was performed to determine the SES factors associated with anti-HAV antibodies positivity. $P$ values $<0.05$ were considered statistically significant.

\section{Results}

Out of the 300 children, 256 were analyzed while forty four were excluded for not meeting the inclusion criteria. All the children were of African descent and boys were slightly more than girls (137 boys, 119 girls). The overall HAV antibodyseroprevalence in this population was $44.5 \%$. The age distribution is shown in Table 2.

There were 189 children from low SES and 107 from high SES with varied distribution as shown on Figure 1.

Table 1. Risk factor attributes for hepatitis A virus.

\begin{tabular}{|c|c|c|}
\hline & 1 & 2 \\
\hline Type of house & Permanent & Semi permanent or Shanty \\
\hline Water supply & Running tap in the house & $\begin{array}{l}\text { Running tap outside or communal } \\
\text { well/river/from a vendor }\end{array}$ \\
\hline Sanitation & Flush toilet in the house & $\begin{array}{l}\text { Communal flush toilet or pit latrine } \\
\text { outside or no defined facility }\end{array}$ \\
\hline Crowded household & Low crowded house ( 1 - 4 people) & High crowded house ( 4 - 9 people) \\
\hline $\begin{array}{l}\text { Parents level of } \\
\text { education }\end{array}$ & $\begin{array}{l}\text { Both parents with secondary } \\
\text { education and above }\end{array}$ & $\begin{array}{l}1 \text { or } 2 \text { parents with primary education } \\
\text { or none }\end{array}$ \\
\hline Parents income & High $>\$ 15$ a day & Low $<\$ 3$ a day \\
\hline
\end{tabular}

1 = High SES, 2 = Low SES.

Table 2. Distribution of children according to age group.

\begin{tabular}{ccc}
\hline Age group & Number & Percentage \\
\hline $2-4$ & 80 & 31.3 \\
$5-9$ & 109 & 42.6 \\
$10-14$ & 67 & 26.2 \\
Total & 256 & 100 \\
\hline
\end{tabular}


When age specific seroprevalence of HAV antibodies were analyzed against socioeconomic status, it was found that generally children from a higher socioeconomic state had low antibody seroprevalence (Table 3).

On subjecting variables of SES to logistic regression analysis, it was shown that factors associated with presence of HAV antibodies were related to age, crowding, parents income, residential area, source of water supply and parent's level of education level in a descending order (Table 4 ).

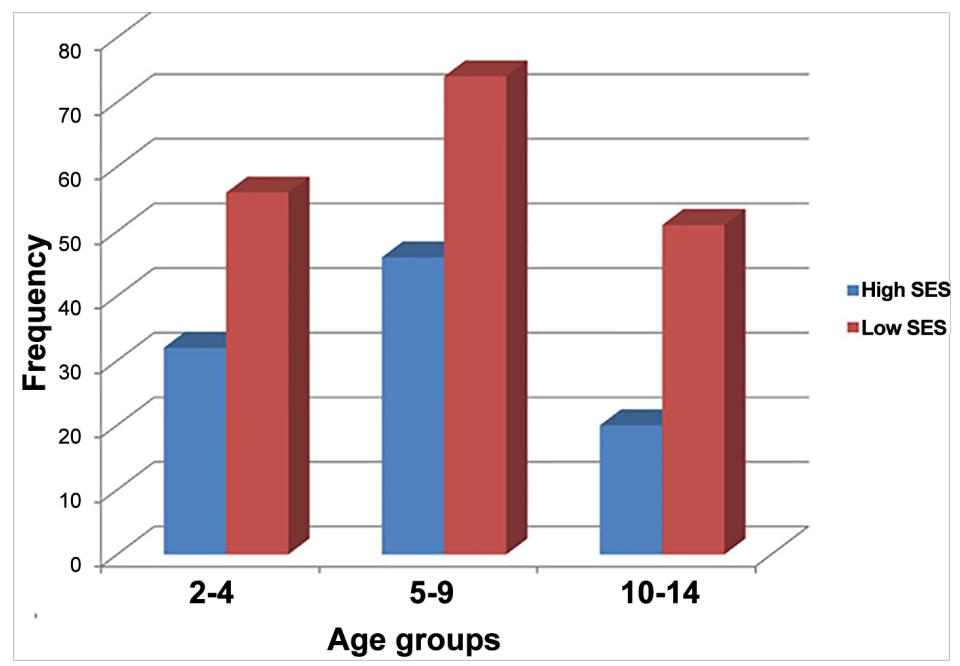

Figure 1. Distribution of children by age groups and socioeconomic states.

Table 3. Age specific antibody seroprevalence of HAV.

\begin{tabular}{ccc}
\hline Age group & Socioeconomic status & \% seroprevalence \\
\hline \multirow{2}{*}{$2-4$} & High SES & 3.8 \\
& Low SES & 37 \\
\multirow{2}{*}{$5-9$} & High SES & 14.6 \\
& Low SES & 61.8 \\
\multirow{2}{*}{$10-14$} & High SES & 38.9 \\
& Low SES & 77.6 \\
\hline
\end{tabular}

Table 4. Factors associated with presence of HAV antibodies.

\begin{tabular}{ccccccc}
\hline \multirow{2}{*}{ Factor } & \multicolumn{2}{c}{ \% seronegativity } & & Relative \\
risk & High SES & Low SES & & $\begin{array}{c}\text { Lower } \\
\text { limit }\end{array}$ & $\begin{array}{c}\text { Upper } \\
\text { limit }\end{array}$ \\
\cline { 2 - 3 } Parents income & 71.4 & 32.3 & $<0.05$ & 2.2 & 1.7 & 2.8 \\
Source of water & 70.5 & 28.3 & $<0.05$ & 2.5 & 2.8 & 3.4 \\
Residential area & 66.9 & 30.2 & $<0.05$ & 2.2 & 1.6 & 3.0 \\
Parents level of education & 72.7 & 20.0 & $<0.05$ & 3.6 & 2.4 & 5.6 \\
Crowded household & 70.4 & 36.7 & $<0.05$ & 1.9 & 1.5 & 2.4 \\
Age & 73.2 & 34.6 & $<0.05$ & 3.8 & 2.8 & 5.8 \\
\hline
\end{tabular}

$\mathrm{P}^{*}$ : degree of significance. 


\section{Discussion}

The results of this study are in keeping with findings of previous studies [10] [11] [12] that HAV antibody seropositivity increased significantly with advancing age and was significantly different in every age group $(\mathrm{P}<0.05)$. Our study indicates a significant shift in the pattern of HAV epidemiology in Kenya. In previous findings it was observed that most African countries such as Kenya, had very high rates of HAV infection and nearly all children by the age of 5 years had been infected [13]. The epidemiological shift may be attributed to improved socioeconomic status, improved public sanitation, use of chlorinated water and increased level of parental education. Hepatitis A virus seroprevalence rate is directly related to socioeconomic development of a particular society. For example, in developed countries such as North American states, Austria and Norway, seropositivity rates are low ranging from $2 \%$ and $20 \%$ in adolescence [14]. On the contrary, seropositivity rates in developing countries range between $50 \%$ and $100 \%$ until adult age and are related to poor socioeconomic development [15] [16] [17].

In deed when low and high socioeconomic status children are compared, the latter tend to have a pattern close to those of developed countries while the former have similar patterns to those of developing nations (Table 5).

Results from the current study shows that disease acquisition among the high SES population occurs in early adolescence and may proceed on to early adulthood rather than in early childhood. This may coincide with young adults' closer interaction at school, involvement in risky behaviours such as poor hand hygiene and interacting more and more with street populations [1] [2] [18]. The implication is that a low level of HAV immunity among young adult population puts them at a higher risk of outbreaks and severer symptomatic infections [13] [19].

Table 5. The HAV antibody seroprevalence age groups in several countries.

\begin{tabular}{ccc}
\hline Country & Age group (years) & HAV seroprevalence \\
\hline United Kingdom & $5-9$ & 10.5 \\
(Das et al., 2000) & $10-14$ & 13.9 \\
& $15-19$ & 19.6 \\
Italy (Fix et al., 2002) & $3-5$ & 2.3 \\
& $17-19$ & 16.3 \\
India (Baudin et al., 1971) & $6-10$ & 62.2 \\
& $11-15$ & 68.5 \\
Current study (Kenya) & Over 16 & 80.8 \\
Low SES High SES & $5-9$ & 61.8 \\
& $10-14$ & 77.6 \\
& $5-9$ & 14.6 \\
\hline
\end{tabular}


This study reported a negative correlation between parental education level and HAV antibody seroprevalence. This has also been observed in other previous studies [17] [20]. It has been noted that parental education level has a direct effect on lifestyle led by the family through influencing sanitation, living in a less crowded area and thus being accessible to portable treated water [21]. On the contrary children from a low SES, whose parental level of education was low, may have been exposed to negative environmental factors that facilitated hepatitis A transmission and hence infection.

Notable is that HAV vaccines that have been available just before the beginning of the millennium providing consistent and long-lasting protection [22] have not been fully utilized in our setting. Countries such as the United States where vaccination programs have been executed in high endemic areas have reported very low outbreaks of HAV infections amongst young adults [9]. In Kenya, our national immunization program does not include HAV vaccine. We recommend that vaccination against HAV in preschool-aged children and more so children from higher SES settings should be considered to mitigate future morbidity and mortality arising from HAV infection.

\section{Conclusion and Recommendation}

These results show a considerable rate of HAV antibody seronegativity amongst the studied population especially those from richer backgrounds making them more susceptible to severe infection in future, with concomitant complications. We propose that revision of National Vaccination Program should be considered to include Hepatitis A vaccination.

\section{Acknowledgements}

We wish to thank the children and their parents who agreed to take part in this study, KNH/UoN-ERC for approving the study, the AgaKhan University hospital, Nairobi Education committee for allowing the study in the hospital. The Department of Peadiatricsand Child Health, University of Nairobi, Research Laboratory for analyzing the specimens and Aventis Pasteur for funding the study.

\section{Limitation}

This study limited to specific regions of Nairobi but represented populations of different socioeconomic states that were envisioned for in this study.

\section{Conflict of Interest Statement}

The authors have no conflict of interest concerning the work reported in this paper.

\section{Author Contribution}

Conceptualization and proposal development: A. W.

Data collection: A. W., M. J. R., H. M.

Data analysis and manuscript preparation: A. W., F. M., M. M. O. 


\section{References}

[1] Lemon, S.M. (1985) Type A Viral Hepatitis: New Developments in an Old Disease. The New England Journal of Medicine, 313, 1059. https://doi.org/10.1056/NEJM198510243131706

[2] Gust, I.D. (1992) Epidemiological Patterns of Hepatitis A in Different Parts of the World. Vaccine, 1, S56-S58. https://doi.org/10.1016/0264-410X(92)90544-T

[3] Papaevangelou, G. (1992) Epidemiology of Hepatitis A in Mediterranean Countries. Vaccine, 10, S63-S66. https://doi.org/10.1016/0264-410X(92)90546-V

[4] Cuthbert, J.A. (2001) Hepatitis A: Old and New. Clinical Microbiology Reviews, 14, 38-58. https://doi.org/10.1128/CMR.14.1.38-58.2001

[5] Wei, S.C. (2002) Comparison of Clinical Manifestations and Epidemiology between Acute Hepatitis A Andacute Hepatitis E in Taiwan. Journal of Gastroenterology and Hepatology, 17, 1187-1191. https://doi.org/10.1046/j.1440-1746.2002.02858.x

[6] Prodinger, W.M., Larcher, C., Solder, B.M., Geissler, D. and Dierich, M.P. (1994) Hepatitis A in Western Austria-The Epidemiological Situation before the Introduction of Active Immunisation. Infection, 22, 53-55.

[7] Beutels, M., Van Damme, P., Vranckx, R. and Meheus, A. (1998) The Shift in Prevalence of Hepatitis A Immunity in Flanders, Belgium. Acta Gastro-Enterologica Belgica, 61, 4-7.

[8] Hollinger, F.B., Ed. (2005) Global Impact of Hepatitis A Virus Infection: Changing Patterns in Viral Hepatitis and Liver Disease. Williams and Wilkins, Baltimore, 14-20.

[9] Practices, A. (1999) Prevention of Hepatitis A through Active or Passive Immunization. Morbidity and Mortality Weekly Report, 48, 1-37.

[10] Mall, M.L., Rai, R.R. and Philip, M. (2001) Seroepidemiology of Hepatitis A Infection in India: Changing Pattern. Indian Journal of Gastroenterology, 20, 132-135.

[11] Akbulut, A. (2003) HAV Infection in Turkey. Turkish Association for the Fight against Viral Hepatitis, 57-84.

[12] Wang, S.M., Liu, C.C., Huang, Y.S., Yang, Y.J. and Lei, H.Y. (2001) Change in Hepatitis A Virus Seroepidemiology in Southern Taiwan: A Large Percentage of the Population Lack Protective Antibody. Journal of Medical Virology, 64, 104-108. https://doi.org/10.1002/jmv.1024

[13] Jacobsen, K.H. and Koopman, J.S. (2004) Declining Hepatitis A Seroprevalence: A Global Review and Analysis. Epidemiology and Infection, 132, 1005-1022. https://doi.org/10.1017/S0950268804002857

[14] World Health Organization (2000) Hepatitis A. WHO/CDS/CSR/EDC/2000-7, World Health Organization, Geneva.

[15] Baudin, A.L. and Gaumer, B. (1971) Situation épidémiologique du gouvernerat de Sousse en 1970. La Tunisie Médicale, 49, 213-217.

[16] Das, K., Jain, A., Gupta, S., Kapoor, S., Gupta, R.K., Chakravorty, A., et al. (2000) The Changing Epidemiological Pattern of Hepatitis A in an Urban Population of India: Emergence of a Trend Similar to the European Countries. European Journal of Epidemiology, 16, 507-510. https://doi.org/10.1023/A:1007628021661

[17] Fix, A.D., Martin, O.S., Gallichio, L., Vial, P.A. and Lagos, R. (2002) Age-Specific Prevalence of Antibodies to Hepatitis A in Santiago, Chile. Risk Factors and Shift in Age of Infection among Children and Young Adults. American Journal of Tropical Medicine and $\mathrm{Hy}$ giene, 66, 628-632.

[18] Tanaka, J. (2000) Hepatitis A Shifting Epidemiology in Latin America. Vaccine, 18, S57- 
S60. https://doi.org/10.1016/s0264-410x(99)00466-1

[19] Scheifele, D.W. (2005) Hepatitis A Vaccines: The Growing Case for Universal Immunisation of Children. Expert Opinion on Pharmacotherapy, 6, 157-164.

https://doi.org/10.1517/14656566.6.2.157

[20] Erdogan, M.S., Otkun, M., Otkun, M.T., Akata, F. and Ture, M. (2004) The Epidemiology of Hepatitis A Virus Infection in Children, in Edirne, Turkey. European Journal of Epidemiology, 19, 267-273.

[21] Demicheli, V. and Tibert, D. (2003) The Effectiveness and Safety of Hepatitis A Vaccine: A Systematic Review. Vaccine, 21, 2242-2245.

https://doi.org/10.1016/S0264-410X(03)00135-X

[22] Furesz, J., Scheifele, D.W. and Palkonyay, L. (1995) Safety and Effectiveness of the New inactivated Hepatitis A Virus Vaccine. CMAJ, 152, 343-348.

\section{Submit or recommend next manuscript to SCIRP and we will provide best service} for you:

Accepting pre-submission inquiries through Email, Facebook, LinkedIn, Twitter, etc.

A wide selection of journals (inclusive of 9 subjects, more than 200 journals)

Providing 24-hour high-quality service

User-friendly online submission system

Fair and swift peer-review system

Efficient typesetting and proofreading procedure

Display of the result of downloads and visits, as well as the number of cited articles

Maximum dissemination of your research work

Submit your manuscript at: http://papersubmission.scirp.org/

Or contact ojped@scirp.org 